Cad. Benjaminianos, Belo Horizonte, v. 13, n. 2, p. 337-358, 2017

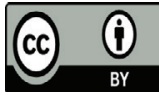

\title{
Um estudo na literatura da Shoah com Walter Benjamin e Gaston Bachelard
}

\section{A study of the Shoah literature using Walter Benjamin and Gaston Bachelard}

\author{
Alecrides Jahne Raquel Castello Branco de Senna \\ Universidade Federal do Rio Grande do Norte (UFRN), Natal, Rio Grande do Norte / Brasil \\ alecrides@hotmail.com
}

Resumo: Em momentos históricos marcados pela violência infligida ao Outro, refletir sobre as marcas deixadas pelo sofrimento resultante de contextos sociais marcados pela violência, não é algo do qual a sociologia deve se eximir. Muito tem sido produzido sobre a Shoah (Catástrofe, em hebraico) e, igualmente, sobre a literatura resultante dos relatos escritos pelos sobreviventes. Esse estudo é uma tentativa de leitura desses relatos, dos campos de concentração nazistas, da segunda guerra mundial (1939-1945), e tem seu embasamento teórico em Walter Benjamin e Gaston Bachelard. Entendendo os relatos enquanto resgates de momentos históricos a partir da memória, faz-se uma discussão com os conceitos de Jeztzeit, Erfahrung e Erlebnis de Benjamin e, a concepção de instante de Gaston Bachelard. Na tentativa de colocar em constelação imagens do Lager, a leitura é feita numa perspectiva bachelardiana de repercussão e ressonância como instrumentos para uma atualização das imagens - que repercutem no pesquisador e produzem ressonâncias, que se associam às escolhas teóricas. Ao mesmo tempo em que incidem sobre uma preocupação específica, que foi o ponto de partida que é a substituição do nome pelo número no Lager, a leitura dos relatos fez luzir algumas questões que são discutidas ao longo do artigo.

Palavras-Chave: literatura da Shoah; memória; judaísmo. 


\begin{abstract}
During historical moments marked by the violence inflicted on the Other, reflecting on the scars left by such suffering is not something that sociology should exempt itself from. Much has been produced on the Shoah (catastrophe in Hebrew) and also on the literature resulting from memoirs and accounts from its survivors. This study is an attempt to read these accounts from the Nazi concentration camps in World War II (1939-1945), and rests its theoretical basis in Walter Benjamin and Gaston Bachelard. By understanding those memoirs as an attempt to trace those historical incidents out from the memory, a discussion on the concepts of Jeztzeit, Erfahrung and Erlebnis as conceived by Benjamin is made; as well as on the concept of instant to Gaston Bachelard. In an attempt to create a constellation through images of the Lager, the reading is made in a Bachelardian perspective of repercussion and resonance. That is: instruments for an attempt to update such images, which are associated with theoretical choices, while focusing on a specific concern - a replacement of the name by a number on.
\end{abstract}

Keywords: literature of the Shoah; memory; Judaism.

Nunca me esquecerei daquela noite, a primeira noite de campo, que fez da minha vida uma noite longa e sete vezes aferrolhada. Nunca me esquecerei daquela fumaça.

Nunca me esquecerei dos rostos das crianças cujos corpos eu vi se transformarem em volutas sob um céu azul e mudo.

Nunca me esquecerei daquelas chamas que consumiram minha fé para sempre. Nunca me esquecerei daquele silêncio noturno que me privou por toda a eternidade do desejo de viver.

Nunca me esquecerei daqueles momentos que assassinaram meu

Deus, minha alma e meus sonhos, que se tornaram deserto.

Nunca me esquecerei daquilo, mesmo que eu seja condenado a viver tanto tempo quanto o próprio Deus. Nunca.

(Elie Wiesel, em “A Noite”, 2006, p.42).

\title{
10 movimento das imagens do Lager
}

O tempo da memória é como o som do silêncio. Como uma música que se repete ininterruptamente, fechando um círculo; as cadências definem as subidas e descidas em espiral. As imagens de memória estão 
sempre à espreita, como uma sombra protegida; pela escuridão. Como uma música que, constantemente repetida, deixa de se ouvida.

Sobre a chegada a Auschwitz, diz Primo Levi, "Tudo era silencioso como num aquário, e como em certas cenas dos sonhos" (LEVI, 2010a, p. 18). A primeira impressão era a de um sonho, de algo irreal. Haviam passado para o outro lado. E, deste, os primeiros sons são de 'latidos bárbaros', uma babel, de onde a única coisa inteligível é a violência gratuita.

A imagem que vem das profundezas não possui voz inteligível à primeira escuta. Ela produz sentimento. Damos voz a ela quando precisamos descrevê-la, transliterar o sentimento por ela produzido. Ela vai adquirindo voz à medida que produz ressonâncias em nossa atualidade. Atualizamos as vozes à medida que reproduzimos os ecos. De repercussão em repercussão, as espirais constroem novos "eus" que precisam suas imagens, atualizando-se continuamente.

Esse constante refazer-se tem por base a Experiência (Erfahrung). Mergulhado no curso do rio da Vivência (Erlebnis), vai à tona para respirar vez ou outra, ou quando tropeça em algo no fundo do rio. Não existe regra, fórmula, palavra-chave, as circunstâncias definem o momento, o Jetztzeit. Não é algo que possa ser controlado ou induzido. É um encontro de instantes, esquecidos nas sombras da memória.

Olhar para os relatos, é como olhar para momentos, uma cadeia reluzente de instantes. Uma compreensão, um diálogo com as imagens de memória. Diálogo este que proporcionará a outros um contato e possível diálogo. Como assistir ao filme $O$ pianista, que levou o pesquisador a outros pastos, a reflexões as mais diversas, sobre si mesmo. Não como uma cadeia, pois, não implica uma sequenciação (uma narrativa linear), mas uma constante atualização de imagens.

A transliteração desses textos em filmes é o exemplo de uma forma de atualização. A leitura feita por Roman Polanski do texto de Szpilman (2008) levou à produção do filme que, entrementes, carrega consigo a voz do próprio Polanski, que ouço na voz da personagem Dorota: "eu não queria vir, não queria ver isso". Repercute no pesquisador como "não queria ver tudo isto". Pois, mais que o filme, a leitura proporciona um período mais longo de reflexão. "Ler é sonhar pela mão de outrem" (PESSOA, 2006, p. 233), diz o poeta, ainda que de forma depreciativa, aqui, a frase tem outro significado: ler é sonhar através dos sonhos de outrem.

Inicialmente, repercussão/ressonância parecem referir-se ao plano da Erfahrung e não, da Erlebnis. A imagem que nos joga nas profundezas 
da repercussão marca a Erfahrung - essa espiral que outra experiência poderá remeter a si. A Erlebnis perde-se na escuridão do esquecimento, é jogada ao Lete distraidamente, como algo tão óbvio que sequer tangencia a alma, uma "vivência imediata" típico de sociedades urbanas e industriais (LÖWY, 2005, p. 28).

Não se trata aqui de retomar a discussão sobre modernidade e pósmodernidade ${ }^{1}$ e sua relação com a memória e o Holocausto. Mas, de reportar a uma concepção de história específica, em que os relatos da Shoah não se desloquem apenas como material ilustrativo. São imagens, mas, também, momentos históricos que possuem um peso moral importante. O peso dessa importância pode ser sentido na capacidade de repercussão dessas imagens.

Em seu texto "Experiência e Pobreza" (o título inicialmente seria "Pobreza de experiência"), Benjamin refere-se à primeira guerra mundial, onde "Não se tinha, naquela época, a experiência de que os homens voltavam mudos dos campos de batalha?" ( $O$ anjo da historia, 2012, p. 86). Não falavam não porque não se tinha o que falar, mas por não possuírem "experiências partilháveis" (idem). As experiências dos campos de concentração seriam compartilháveis? Qual a diferença entre as épocas que as torna compartilháveis em alguma medida? A experiência da primeira guerra, a compreensão de uma mudança radical operada no mundo pela consciência das guerras bélicas, talvez.

As duas grandes guerras modificaram a forma de ver e sentir o sofrimento. Susan Sontag (2003) diz que os meios de comunicação levaram a guerra para dentro das casas e isso insensibilizou o olhar para o sofrimento do outro. A frequência das tragédias, as imagens de sofrimento ao lado de anúncios de produtos e outras propagandas, colocou em evidência a realidade da dor enfrentada em outras partes do globo.

Mas, isso não inviabiliza a necessidade dessa discussão, ao contrário, intensifica. Os relatos em si, já possuem imagens potentes, capazes de mobilizar o pensamento e a reflexão sobre o sofrimento, sobre os atos de guerra e a capacidade humana de empreender tragédias. A Shoah, a catástrofe não é a irrupção de algo que vem de fora da humanidade - mas, a quebra de uma corrente simbiótica ${ }^{2}$ que faz o humano.

\footnotetext{
${ }^{1}$ Sobre isso ver "Modernidade e Holocausto" de Zygmunt Bauman.

${ }^{2}$ Lembro-me do filme "O óleo de Lorenzo" (Kennedy Miller, 1992) e da discussão sobre a ALD (Adrenoleucodistrofia), em que as moléculas de gordura que danificavam o organismo eram fabricadas pela mesma enzima. A questão, em suma, era um desequilíbrio das funções que provocavam o aumento da gordura ruim.
} 
Jorge Semprún fala em seu $A$ escrita ou a vida, que, sentia-se imortal. Havia alcançado a imortalidade pelas experiências do Lager. Não fisicamente, mas, em seus sentimentos mais profundos. Sua condição moral o fazia sentir-se fora do mundo, sobre o humano. Ler Semprún afirmar isso, ergue uma cadeia de juízos: mas, ele agora teria o direito de se vingar agredindo a quem o desagradasse? Ele poderia roubar, pois estaria no direito, já que foi espoliado da própria vida? ${ }^{3}$

A experiência do lager o fazia sentir-se acima do mundo real. Quanto Sontag (2012) diz que o sofrimento do Outro deixou de ser o meu sofrimento, tudo isso se desfaz quando o sentimento de injustiça recai sobre a minha cabeça. Sofrer uma agressão por alguém que sofreu num campo de concentração nazista coloca uma questão que coloca a nu, questões morais superficiais. O problema da injustiça nos faz questionar o que é justiça. Como diz o poeta: "quando está com raiva, tem o direito de estar com raiva, mas isso não dá a você o direito de ser cruel". ${ }^{4}$

Libertadas, as garotas seguiam de trem para a Suécia e, durante todo o trajeto, quando percebiam que se tratava de sobreviventes dos campos de concentração, as pessoas jogavam chocolates, dinheiro, entre outras coisas, para as garotas (Herson, 2006). O trem que seguia, levando os prisioneiros para os campos mais distantes do front, vagões de gado abertos, com figuras esqueléticas - 'uma carga que as pessoas nunca tinham visto' - os faziam jogar pedaços de pão para dentro dos vagões:

Um pedaço caiu em nosso vagão. (...) Vi, não longe de mim, um velho que se arrastava, engatinhando. Estava saindo da briga. (...)

Uma sombra acabara de se projetar ao seu lado. E essa sombra se jogou em cima dele. (...)

O velho ainda murmurou alguma coisa, deu um suspiro e morreu, $\mathrm{em}$ meio à indiferença geral. $\mathrm{O}$ filho o revistou, pegou o pedaço $\mathrm{e}$ começou a devorá-lo. Dois homens o tinham visto e se atiraram em cima dele. Outros se juntaram a eles. Quando se retiraram, havia perto de mim dois mortos lado a lado, pai e filho. Eu tinha quinze anos. (WIESEL, 2006, p. 105-106).

\footnotetext{
${ }^{3}$ Temos o receio de fazer certas perguntas que poderiam parecer politicamente incorretas - ou, ainda, que levem à questão a outro nível. Mas, trata-se justamente disso: em quais níveis deveríamos discutir as imagens do Lager? Pois, a repercussão se dá, de fato - mas, a quê ela remete?

${ }^{4}$ Atribuído a Shakespeare.
} 
Após a libertação de Buchenwald, Jorge Semprún ficou com os exércitos aliados apenas o tempo necessário para a recuperação física suficiente para viajar. Juntou-se ao grupo que seguiu em um caminhão para a cidade de Paris. Lá, passou anos perambulando. Dormia na rua, em apartamentos vazios, em casa de amigos. Como Levi, Semprún observa que algumas pessoas sentiam-se desconfortáveis com a sua imagem - e o que ela evocava. Não conseguia falar sobre o campo. Seu relato foi escrito quase quarenta anos depois. Ele teve pesadelos constantes, durante anos. Uma dor que só podia ser expressa com um grito vindo do fundo da alma. Ao escrever seu relato, diz "Tornei-me mortal outra vez" (WEINRICH, 2001, p. 267).

O problema da experiência na modernidade, para Benjamin, está relacionada à interioridade. Esse é o elo da questão: muitos vivem "Mais no seu interior do que na sua interioridade - e é isso que as torna bárbaras" (BENJAMIN, 2012, p. 87). Essa distinção aparece mais claramente quando ele diz:

$\mathrm{Na}$ verdade, de que nos serve toda a cultura se não houver uma experiência que nos ligue a ela? A detestável mistura de estilos e de visões do mundo do século passado mostrou-nos tão claramente aonde leva o uso hipócrita e simulado da experiência, que é uma questão de honra confessar hoje a nossa pobreza. (BENJAMIN, 2012, p. 86).

Löwy, citando Benjamin, fala sobre a importância dos dias de festa, pois eles permitem o "reencontro com uma "vida interior"' (2005, p. 29). No lager, os judeus religiosos preocupavam-se com o cumprimento das mitsvot. ${ }^{5}$ Apenas algumas infrações são permitidas, para salvar uma vida. Entretanto, manter-se firme no cumprimento das mitsvot é uma forma de suster o mundo, de elevação, necessário para a vinda do Mashiach. ${ }^{6}$

- Bendigam o Eterno...

A voz do oficiante mal acabava de ser ouvida. Pensei, a princípio, que fosse o vento.

- Bendito seja o nome do Eterno!

Milhares de bocas repetiam a bênção, prosternavam-se como árvores na tempestade. (WIESEL, 2006, p. 73-74).

\footnotetext{
${ }^{5}$ Conjunto de 613 leis.

${ }^{6}$ Messias.
} 
Um rabino mantém-se firme em sua decisão de jejuar no Yom Kippur: o dia do perdão é um dia de jejum. Não se pode comer ou beber. Deve-se passar o dia em oração. A celebração é longa e leva em conta os pecados do ano inteiro. O oficial que recebe a recusa de comida do rabino admira-se como alguém, naquela situação, ainda recusa-se a comer: "O ano inteiro era Yom Kippur. Mas outros diziam que devíamos jejuar, justamente porque era um perigo fazê-lo. Era preciso mostrar a Deus que mesmo aqui, neste inferno cercado, éramos capazes de cantar Seus louvores" (WIESEL, 2006, p. 76).

É o momento de confrontar-se consigo mesmo, para o jovem Elie Wiesel, quando o Yom kippur, a celebração tão conhecida e repetida passa por ele como o som do silêncio, levada pelo vento:

Eu não jejuei. Em primeiro lugar, para agradar ao meu pai, que me proibira de fazê-lo. Depois, eu não via nenhuma razão para jejuar. Não aceitava mais o silêncio de Deus. Engolindo minha tigela de sopa, via naquele gesto um ato de revolta e de protesto contra Ele.

E eu roia o meu pedaço de pão.

No fundo do meu coração, sentia que se abrira um grande vazio. (WIESEL, 2006, p.76)

Um manuscrito encontrado em parte dos espólios de Benjaminm apresenta um conjunto de teses que trazem algumas ideias elucidativas e o que é mais significativo aqui é: "A imagem dialética é um relâmpago em forma de cone que atravessa todo o horizonte do passado." ( $O$ anjo da historia, 2012, p.179). Ele atravessa o horizonte na medida em que o tempo é momento. Um momento que pode ser apreendido, tocado, tangenciado, visualizado. Ele diz: "Na medida em que o passado sem concentra no instante - na imagem dialética -, ele entra na memória involuntária da humanidade" (idem, p.179). Essa memória não é senão a cultura.

A Shoah entra na cultura judaica no momento em que lembrar é preciso e o Yom HaShoah (GORODOVITS, 2008) é o rastro, a marca, a cicatriz no corpo para a qual se olha e remete à lembrança. E,

Compreender não significa negar nos fatos o chocante, eliminar deles o inaudito, ou, ao explicar os fenômenos, utilizar-se de analogias e generalidades que diminuam o impacto da realidade e o choque da experiência. (...) Compreender significa, em suma, encarar a realidade sem preconceitos e com atenção, e resistir a ela - qualquer que seja. (ARENDT, 1989, p.12) 
A Shoah é a sombra por trás da Vivência, a barbárie que corre pelo subsolo em que a humanidade renasce, vive, morre. As vítimas do horror nos lembram, em seus relatos, aquilo para o qual fechamos os olhos: sabemos, secretamente, que em algum momento estaremos empunhando a arma. Mergulhar nas imagens da Shoah é enfrentar a barbárie dentro de cada pessoa. Enfrentar o momento histórico é uma forma de produzir um conhecimento mais aproximado possível de uma imagem dialética, que "A imagem dialética deve ser definida como a memória involuntária da humanidade redimida" (BENJAMIN, 2012, p. 179). É ela mesma a imagem de um instante.

\section{0 tempo em espiral}

Escrever, contar é "criar lugares comuns" (LÉVINAS, 2008, p. 66). A linguagem é lugar de encontro. Ao acessar os relatos, acesso outro mundo. Entretanto, nos relatos, não há uma ordem cronológica. Como nos poemas, os relatos são acessados como imagens. Como a memória, eles surgem como clarões que sobem à consciência.

Szpilman (2008) diz que o tempo que passou no gueto é como um bloco de memória. Ele não consegue organizar em ordem cronológica. Durante seu relato, aparecem várias tentativas de 'localizar' as memórias dentro da linha do tempo, especialmente na época em que esteve solitário:

Chegaram o natal e o ano-novo de 1945: o sexto período das festas de fim de ano desta guerra, o pior de todos que já passara até agora e, provavelmente, o mais difícil de sobreviver. Passei-o deitado no escuro, ouvindo o uivar do vento nos restos dos telhados (...). Lembrava-me das festas anteriores, as de antes da guerra e mesmo as dos primeiros anos de ocupação alemã: eu tinha uma casa, meus pais e meus irmãos. (SZPILMAN, 2008, p. 176).

A localização dos momentos está conectada às festividades de final de ano: natal e ano-novo. O elemento que, na visão de Benjamin, religa o homem atual ao homem anterior. É o tempo dos calendários, e não dos relógios. O tempo que é passível de fixar na memória. A lógica do texto constelar não permite, por isso, uma descrição linear: "a leitura do texto constelar se caracterizaria pela liberdade de estabelecer ligações entre partes dispersas" (OTTE, 2000, p. 39). Essas mesmas partes dispersas são evidenciadas nos relatos. É como "nos sonhos": 
Hoje, quando tento me lembrar de tudo que passei no gueto de Varsóvia durante quase dois anos, de novembro de 1940 a junho de 1942, as lembranças se fundem numa só imagem, com se tudo tivesse durado apenas um dia. Por mais que tente, não consigo desdobrá-las em partes e arrumá-las em ordem cronológica, como normalmente se faz quando se escreve um diário. (SZPILMAN, 2008, p. 51).

Como visto anteriormente, nas memórias de Wiesel, as festas são relatadas como grandes momentos. A praça de chamada era o local das grandes memórias. Na praça de chamada, o 'anjo de olhos tristes' é enforcado. ${ }^{7}$ É lá que o Lager iguala a todos enquanto 'fantasmas de pijamas listrados'. Sombras passeiam pela praça de chamada. Sombras declamam à luz do dia seus infortúnios e indignações em forma de poemas. É possível imaginar e difícil sonhar pela mão de Semprún (1995).

Essa verticalização entra num processo de constelação-ressonâncias - que cria um contexto de compreensão desses aspectos particulares da experiência dos sobreviventes no Lager. Cada leitor é capaz de promover constelações, a partir das imagens que verticaliza. Nenhuma compreensão é capaz de se referir a não ser a um momento histórico em constelação.

$\mathrm{O}$ caminho reverso que o leitor faz em direção às imagens dos relatos - reverso de um caminho percorrido pelo sobrevivente na representação das suas imagens da memória. Prospecção e retrospecção (LÉVINAS, 2008, p. 113) - atualização constante de si, representação do instante, perpassados pela imaginação e linguagem.

A verticalidade está imbuída de ambiguidade no instante poético: "Ora, o tempo é uma ordem, e nada mais que uma ordem." (BACHELARD, 2010, p. 95). Como no exemplo da lamentação risonha, ele diz que "as simultaneidades acumuladas são simultaneidades ordenadas" (2010, p. 95). Afinal, como é possível lamentar e rir? Em Szpilman, Levi e Semprún, algumas imagens estão imersas num instante poético. Uma atualização revitalizada por um "olhar de fora", um olhar para um sonho, o olhar do sobrevivente. Essa é a ordem do instante: "A meta é a verticalidade, a profundidade ou a altura; é o instante estabilizado em que as simultaneidades, ordenando-se provam que o instante poético tem uma perspectiva metafísica" (2010, p. 94).

\footnotetext{
${ }^{7}$ WIESEL, 2006, p.72.
} 
Isto é o inferno. Hoje, nos nossos dias, o Inferno deve ser assim, um local grande e vazio, e nós, cansados de estar de pé, com uma torneira a pingar água que não se pode beber, esperamos algo sem dúvida terrível e nada acontece e continua a não acontecer nada. Como pensar? Já não se pode pensar, é como estar já morto. Alguns sentam-se no chão. O tempo passa gota após gota. (LEVI, 2010a, p. 21)

Vazio de acontecimentos, de profundidade, de decisões. Vazio de pensamentos. O inferno é a repetição surda do nada. Um nada que ainda não é a morte, mas também não é a vida. Um nada que mantém em suspenso, que corre pelo subsolo e não inflige mudanças à superfície. Afundar no Lager é mergulhar numa profusão de 'nadas', é ser confrontado com a indecisão de ser ou não homem, quando o veredito já foi dado. A quem se pode largar? Ao futuro ou ao passado?

"Essencialmente, o instante poético é a relação harmônica de dois contrários" (BACHELARD, 2010, p. 94). Não seria o encontro do "eu" com o "eu" construído no relato - diante do qual o sobrevivente se coloca como que diante do espelho, o encontro de um "eu" com um "eu-outro"? O encontro de dois opostos? Um Eu que não sou eu. Um não-eu ao qual, de alguma forma, pertenço por imagens de memória, numa relação ambígua?

Benjamin na tese $\mathrm{V}$, diz: “O passado só pode ser apreendido como imagem irrecuperável e subitamente iluminada no momento do seu reconhecimento" (2012, p. 11). Mesmo essa memória não é exatamente como aconteceu. Ela é perpassada pelo presente e só é resgatado pelo olhar do presente:

Quando acabamos, cada um ficou no seu cantinho, e não ousávamos levantar o olhar uns para os outros. Não há espelhos para nos vermos, mas o nosso aspecto está diante de nós, refletido em cem rostos lívidos, em cem fantoches miseráveis e sórdidos. Estamos transformados nos fantasmas que entrevimos ontem à noite. (LEVI, 2010a, p. 25).

A memória se dá apenas a partir do presente. O agora é o momento para essa ruptura, para o reconhecimento do passado, para juntar os fragmentos. É preciso despertar o passado: “As “Teses", portanto, não recorrem apenas à teologia para mostrar que o verdadeiro conceito de história consiste no despertar do passado e de suas vítimas" (OTTE, 2010, p. 50). 
O passado está “no ar", ou seja, está presente, basta sentir, escutar e ver. Nas "Teses", há uma continuidade que não é aquela do continuum do tempo "homogêneo e vazio". A "explosão" deste último, aparentemente um ato destrutivo, apenas acaba com um conceito "catastrófico" de história, possibilitando que as ruínas dispersas, o sopro no ar e as vozes perdidas se juntem novamente para a sua "redenção". (OTTE, 2010, p. 49-50).

Para ele, a noção do presente para Benjamin, e como se dá imagem da rememoração: "As partes da narrativa, que, na superfície linear aparecem como fragmentos desconexos de um discurso onírico, tornam-se significativas quando lidas "verticalmente", ou seja, como "ruínas" manifestas de uma experiência latente" (OTTE; VOLPE, 2000, p. 45). Os pontos da constelação só formam uma imagem à medida que são verticalizados. A narrativa linear quebra-os e os desfaz em fragmentos desconexos, que não podem ser reconhecidos. Pela leitura/concepção linear, mas pela vertical eles recebem novo significado. Em ambos, os significados se transformam.

Por isso a comparação ao tempo dos calendários: "É como se cada ano fosse o anel de uma espiral, sendo que os dias de festa se repetiriam, na superposição dos anéis, sempre no mesmo ponto" (OTTE; VOLPE, 2000, p. 44-45). O passado é uma imagem que chega até nós de uma forma "fugidia": "À maneira dos sinais luminosos que chegam após muito tempo de emitidos pelas estrelas, a recuperação do passado se daria em forma de recordações que cintilam em um momento atual de perigo" (OTTE; VOLPE, 2000, p. 44). Como um sobressalto. Um momento de choque. Ou, como um instante.

É criar mundos comuns. Como diz Lévinas: "Representar não é apenas tornar "de novo" presente, é reconduzir ao próprio presente uma percepção atual que se esvai" (2008, p. 118) e é nesse contexto que se criam os mundos comuns, no campo da linguagem, intermediada por imagens que repercutem e produzem ressonâncias - caminhos reversos. Caminhos com tempo de eternidade: "A representação é puro presente. A posição de um puro presente sem ligação, mesmo tangencial com o tempo, é a maravilha da representação. Vazio do tempo que se interpreta como eternidade." (LÉVINAS, 2008, p. 116).

"Permanecer o mesmo é representar-se" (LÉVINAS, 2008, p. 117), numa tentativa de manter as ligações da memória, dos instantes, pode, também, tornar-se um ciclo, um retorno à memória. Entretanto, 
esse retorno é feito em espiral. Um ciclo de ida e volta na horizontal: "A eternidade dos castigos do inferno talvez tenha quebrado a mais terrível das pontas da ideia antiga do eterno retorno. Coloca a eternidade dos tormentos no lugar onde antes estava a eternidade de um movimento cíclico." (BENJAMIN, 2012, p.179).

É estar no inferno, revivendo o Lager: "Nunca me esquecerei daquela noite, a primeira noite de campo, que fez da minha vida uma noite longa e sete vezes aferrolhada" (WIESEL, 2006, p. 42), ouvir "kremmatorium ausmachen' 8 a cada noite, a cada sono turbulento, a cada palavra que remete ao Lager, que abre um caminho perene de subida em espiral. Para Benjamin, a quintessência do inferno é a repetição: o immergleichen.

\section{Lembrar, Esquecer}

Lembrar e esquecer são as duas faces da memória, segundo Harald Weinrich (2001). Sua obra "Lete: arte e crítica do esquecimento" é um extenso ensaio sobre a relação do homem com a memória e o esquecimento ao longo de séculos. Citando Simônides, Homero, Dante, Cervantes, Helvécio, Kant, Casanova (!), Chamisso, Nietzsche, Freud, Pirandello, Jesus (!), Celan, Primo Levi, Jorge Semprún, Saul Bellow, Bernhard, e Borges, ele nos mostra que memória e esquecimento nem sempre foram entendidos como hoje os entendemos e nem tiveram a mesma importância ou insignificância.

Lembrar ou esquecer? "Muitas coisas então foram ditas e feitas entre nós; mas é bom que delas não se guarde memória." (LEVI, 2010a, p. 14). Alguns acontecimentos daqueles momentos foram considerados como de necessária lembrança, outros, designados ao esquecimento. Enquanto 'jamais esquecer' era prioridade para Wiesel, Semprún observa: "Só o esquecimento poderia me salvar" (1995, p. 160). Ele se detém na intenção de interromper, quebrar o ciclo. Entretanto, ele é jogado diariamente na espiral, através dos pesadelos.

Escrever era um imperativo para muitos sobreviventes, como forma de 'dar testemunho', de contar, de deixar por escrito, expor a nudez da barbárie nazista. Uma espécie de vingança com desejo de justiça, que domina os seres humanos em face de humilhações, tanto quanto a si, como em relação aos outros. Mas, para Semprún, esse desejo de

${ }^{8}$ Semprún, 1995, p. 152. 
escrita foi tolhido pela profundidade do sofrimento que o dominava: "A felicidade da escrita, a essa altura eu já começava a saber, jamais apagava essa desgraça da memória. Muito pelo contrário: aguçava-a, escavava-a, reativava-a. Tornava-a insuportável” (SEMPRÚN, 1995, p. 160).

Ao contrário de Semprún que evitou o Lager por anos, Levi e Wiesel escreveram várias obras de ficção ou não. Para o italiano Levi, escrever era um esforço de extirpar à memória sua característica fundamental: estar na escuridão. Era preciso falar, escrever, para compartilhar, para vingar, para esquecer: Esquecer não é opção e o tempo do esquecimento é o nunca. É a ordem imperiosa do fim, forçado pelas sombras da noite, pela ameaça da não existência: "Nunca me esquecerei daquelas chamas que consumiram minha fé para sempre. Nunca me esquecerei daquele silêncio noturno que me privou por toda a eternidade do desejo de viver." (WIESEL, 2006, p.42)

“Tudo é fato para quem já foi tatuado?" É a pergunta que fica na mente da filha da sobrevivente de Auschwitz (JAFFE, 2012). Nada mais pode chocar ou desestabilizar, desequilibrar, derrubar, quem esteve no Lager. O Lager é a provação máxima da humanidade. É o horror máximo. $\mathrm{O}$ além da linguagem. O Lager tem o poder de destruir os espíritos mais vivazes ou transformá-los em espíritos inabaláveis. Serão esses inacessíveis ou, falta um elo, uma ponte, uma brecha para acessá-los? Dizem os relatos: Auschwitz não parou de acontecer. Ele acontece todos os dias, em todos os lugares. Os relatos levantam redemoinhos na linha histórica definida por alhures e algures, sobre a Shoah.

A espiral está presente, em resistência às tentativas generalizantes. As imagens de memória de Lili, fazem inúmeras voltas em torno do medo: "Aqueles, porém, que não haviam sofrido, ainda não tinham medo" (JAFFE, 2012, p. 25). Ela repete duas vezes algumas páginas antes: eu não tinha medo da morte. E mais à frente, que no relato implicam alguns meses: "Era tanto medo que eu sentia" (p. 28). Era um período intenso de seleções e os crematórios estavam repletos: "Já havia crematórios por toda parte, as chamas altas eram visíveis nas chaminés" (p. 28). Ela estava diante do crematório e sentia medo.

Antes de estar diante desse momento diante do crematório, o sofrimento que produzira o medo:

E começou a me espancar. Acertou-me três vezes: uma na cabeça, outra, nas costas e, pela terceira vez, no peito. Mas isso não lhe bastou. Seguia-me constantemente, mas não as outras. Elas 
passeavam e ela nem ligava. Nós cinco, que já sofremos juntas, sim. Amputaram a perna de uma, operaram a segunda, a terceira; eu tinha feridas até os ossos, que tentava curar sozinha, o tempo todo. (JAFFE, 2012, p. 25)

Lili, como muitos sobreviventes, não falava sobre o campo. Mas suas atitudes sempre apontavam para esse horizonte de sua vida. "Você aguenta", era a frase de sua mãe para situações difíceis, diz Noemi. Não importasse a gravidade da situação a resposta era sempre "Você aguenta". Apenas isso e uma tapinha no ombro.

Lembrar ou esquecer? Mais uma vez ressoa a pergunta. A decisão não é apenas da consciência:" "a dor do recordar, o antigo e feroz sofrimento de me sentir homem, que me assalta como um cão no instante em que a consciência sai da escuridão." (LEVI, 2010a, p. 145), diante das garotas do laboratório no Lager, as lembranças de ser humano o enchem de vergonha. Não apenas pós-Lager, como se pode verno comportamento de Lili Jaffe, Vladek Spiegelman, entre outros. ${ }^{10}$

Em Auschwitz, a fé é um desafio, um dilema. É o jejum do velho rabino, é a indignação roída de Wiesel. É a afirmação da necessidade de manter a fé, dor da perda da fé e a decisão de extirpá-la diante da morte de um ente querido: "Naquele momento, senti que comecei o enterro do meu Deus. Enterrei o meu Adonai para o qual eu sempre rezava." (HERSON, 2006, p. 113). Lembra-se que se é homem ao lembrar-se de esquecer a fé, ou de reafirmá-la: Ainda perdido em seus sonhos cabalísticos, Akiba Drumer encontrara um versículo da Bíblia cujo conteúdo, decifrado, lhe permitia predizer a Libertação para as próximas semanas (WIESEL, 2006).

No Lager o estômago é o único homem, é o tempo do relógio, é caminho entre o tempo e a vida: "O pão, a sopa... eram toda a minha vida. Eu era um corpo. Talvez menos ainda: eu era um estômago faminto. Só o estômago sentia o tempo passar" (WIESEL, 2006, p. 60). Lembra-se que é homem pelo estômago, que lembra a existência do tempo.

A vivacidade da vida deve ser interpretada a partir da consciência? Não será ela apenas, sob o título do erleben, uma consciência confusa ou obscura, somente prévia à distinção do sujeito e do

\footnotetext{
${ }^{9}$ Outro campo no qual não pretendo adentrar é a Psicanálise.

${ }^{10}$ Não se trata de buscar emoções reprimidas, mas imagens que emergem no processo de escrita desses relatos e, a forma como elas são expressas.
} 
objeto, uma pré-tematização, um pré-saber? Não será preciso dizer de outro modo seu psiquismo? (LÉVINAS, 2009, p. 121).

Não será preciso, como no poema de Celan, “dizer de outra forma que não assim"? O titulo de literatura não retira em nada e nem diminui a força da imagem, pois, sendo uma 'necessidade de contar', é uma forma de dizer que, para ler, não se pode pensar como quem lê, mas pensar como quem enxerga. Pensar num movimento constante de objetivação e subjetivação. $\mathrm{O}$ ritmo do pensamento é oscilante.

É no tempo vertical - descendo - que se escalonam as piores dores, as dores sem causalidade temporal, as dores agudas que atravessam um coração para nada, sem jamais enlanguescer. É no tempo vertical - subindo - que se estabiliza a consolação sem esperança, essa estranha consolação autóctone, sem protetor. (BACHELARD, 2010, p. 97-98).

A Erfahrung (Experiência) é como ponte para as imagens de memória que ficam obscurecidas pela Erlebnis (Vivência) - que são acionadas ao sermos lançados nos instantes profundos da repercussão, provocando ressonâncias, necessidades de "representação" (Lévinas), a fim de atingir uma "inteligibilidade do ser". As imagens de memória funcionam como se a Vivência fosse interrompida por "clarões" na consciência.

\section{Tempo e memória em Emmanuel Lévinas}

“Tirar-nos-ão também o nome: se quisermos conservá-lo, teremos de encontrar dentro de nós a força para o fazer, fazer com que, por trás do nome, algo de nós, de nós tal como éramos, ainda sobreviva" (LEVI, 2010a, p. 25-26), aqui, quando Levi descobre que seu nome é 174.517, ele pensa sobre o nome, o seu nome de batismo, o nome pelo qual era chamado pelos pais, parentes, amigos. O nome pelo qual ele se reconhecia como pessoa.

Ao pensar em preservar "algo de nós, de nós tal como éramos", Levi olha para trás. Ele enxerga uma ruptura no tempo. Uma mudança de ventos, um redefinir do fluxo de sua vida. Percebe que a mudança não é apenas no nome. Ele não se torna apenas Häftling, ele se torna um número, torna-se um vulto. Mas, ainda um vulto com lembranças.

Olhar para trás significa estar ainda atrelado às referências àquelas do qual ainda sofrem o processo de espoliação. A chegada ao Lager não é o fim do percurso: "Somos fulminados por esta ideia: ontem 
os nossos viviam, hoje estão todos mortos" (RAJCHMAN, 2010, p. 47). Só a memória do muselmann parece ter sido lançada em um buraco negro de uma consciência velada. É ainda, "voltar atrás na aventura da existência para ser no infinito" (LÉVINAS, 2008, p. 279). É virar o rosto para o finito, mergulhar de novo no fluxo do infinito. "Ser no infinito - a infinição - significa existir sem limites e, sob o aspecto de uma origem, de um começo, ou seja, ainda como um ente." (LÉVINAS, 2008, p. 278), esse infinito refere-se à possibilidade de refazer-se, às possibilidades.

Por isso, o 'olhar para trás' é olhar a partir de algum lugar - nisso confluem as concepções sobre a memória como sendo espacial. Penso que essa espacialidade não se encontre apenas numa forma física, mas, parte também de um lugar na espiral da memória. É preciso pensar a partir de, e, neste caso: "a infinição produz-se pelo ente que existe em verdade" (LÉVINAS, 2008, p. 278).

"A estrutura da consciência ou da temporalidade - da distância e da verdade - está ligada a um gesto elementar do ser que rejeita a totalização." (LÉVINAS, 2008, p. 279), a rejeição da totalização tem em seu cerne a vontade de prolongar, o desejo do infinito. A consciência do tempo enquanto finito embota e desesperança os sentidos: "O rosto imobiliza a totalização." (LÉVINAS, 2008, p. 279). Outro é aquele que me lembra da minha finitude.

Lévinas encontra eco no Instante Bachelardiano ao afirmar que "No retorno do novo instante ao instante antigo reside, de facto, o caráter salutar da sucessão" (LÉVINAS, 2008, p. 280). O que a princípio parece uma contradição ele emenda mais adiante que, o passado e todo seu peso está contido nesse movimento: "instante presente "com o peso de todo passado', ainda que esteja prenhe de todo futuro" (idem, p.280). Nesse encontro de passado e futuro, mediada pelo presente, encontram-se intersecções nos pensamentos, "simultaneidades acumuladas [que] são simultaneidades ordenadas" (BACHELARD, 2010, p.95), em sentido sempre vertical, para a altura ou a profundidade.

"O tempo é o não-definitivo do definitivo, alteridade que está sempre a recomeçar o realizado - o 'sempre' do recomeço" (LÉVINAS, 2008 , p. 281), o tempo retoma sempre, e uma vez mais, aquilo que foi, refazendo, perdoando, remindo a memória. "O instante na sua continuação encontra uma morte e ressuscita" (LÉVINAS, 2008, p. 282). Mas, a 'origem', no caso de Semprún, se via ameaçada: 'De repente, não 
só tornava-se evidente, claramente legível, que eu não estava em casa, como também não estava em lugar nenhum" (SEMPRÚN, 1995, p. 150).

O tempo efêmero, ainda que sentido como eternidade:

Dois anos de eternidade glacial, de intolerável morte separavam-se de mim mesmo. Será que eu regressaria a mim mesmo, um dia? À inocência, fosse qual fosse a preocupação de viver, de uma presença transparente para si mesmo? Seria eu para sempre aquele outro que atravessara a morte? que dela se nutrira? Que nela desmanchara, se evaporara, se perdera? (SEMPRÚN, 1995, p. 108).

E se Experiência/Vivência são distintos e complementares, e, se a Repercussão está na ordem do sentimento e não da reflexão, terá ela relação com a fruição. Entender o movimento entre repercussão/ ressonância - similares ao que Bachelard diz: "é preciso sempre refletir num ritmo oscilatório de objetivação e de subjetivação" (2008, p. 78). É o encontro - e também desencontro - entre fruição e representação que está a primeira ruptura entre repercussão e ressonância. "Na fruição, sou absolutamente para mim" (2008, p. 126), diz Lévinas. A fruição não está atrelada a nenhuma reflexão, ela não se põe em direção ao infinito. Ela é finita, não existe nela duração, continuidade. Apenas momento, pois, "Sensibilidade é fruição" (p. 128).

Fruição se dissipa com as ressonâncias. Não no sentido de que elas possuem uma ponte exata. Ao contrário. A fruição não resiste à duração. Como o instante, que não se repete e que não se prolonga. É apenas como uma vaga sensação. Ela aprofunda aquilo que o caminho não designa, não pode desenrolar:

A qualidade não resiste à identificação, porque representaria um escoamento e uma duração; o seu caráter Elemental, a sua vinda a partir do nada, constitui, pelo contrário, a sua fragilidade, o seu esboroamento de devir, esse tempo anterior à representação - que é ameaça e destruição. (LÉVINAS, 2008, p. 134).

Vejamos a impossibilidade da escrita de imagens. Escrever é um exercício impossível quando a imagem ainda repercute:

Quando acordava às duas horas da manhã, com a voz do oficial SS no meu ouvido, com a chama alaranjada do crematório cegandome a vista, a harmonia sutil e sofisticada do meu plano explodia em dissonâncias brutais. (SEMPRÚN, 1995, p. 158). 
Semprún encontra-se ainda no plano da sensibilidade, não da reflexão. Durante anos foi incapaz de falar sobre o Lager e escrever sobre ele. Evitava como tentativa de enterrar suas imagens de memória. Aquilo de que desejava se livrar, apoderava-se dele em momentos de distração.

Quando Lévinas fala sobre fruição, ele aponta para o que chama de 'elemento'. É o azul do céu. O elemento "não tem formas que o contenham" e "A relação adequada à sua essência descobre-o precisamente como meio: mergulhamos nele" (2008, p. 123). O canto dos pássaros ouvido por Semprún após a libertação. Elemento. Fruição. O sentimento que o recobre e aprofunda na dor. Despertar da sensação de homem liberto. Deixa-se de ser häftlig e torna-se homem ao ouvir o som do canto dos pássaros: "De repente, assalta-me uma aflição. Não é agonia, menos ainda angústia. Muito pelo contrário, a alegria é que perturba: um excesso de alegria" (SEMPRÚN, 1995, p. 83).

A fruição se eleva às alturas, mas também desce às profundezas. É assim como descreve Semprún, a sensação ao ouvir o que ele denomina "o canto das profundezas da terra":

- Está ouvindo?

Não era uma pergunta, a bem da verdade. Eu não podia deixar de ouvir. Ouvia aquela voz desumana, aquele soluço entrecortado, aquele estertor estranhamente ritmado, aquela rapsódia do além.

Era a morte que cantarolava, com certeza, em algum lugar no meio amontoado de cadáveres. A vida da morte, em suma, que se fazia ouvir. A agonia da morte, sua presença fulgurante e funebremente loquaz.

- Ídiche! - exclamou. - Ela fala ídiche!

Assim, a morte falava ídiche.

(SEMPRÚN, 1995, p. 37-38)

A morte cantava em ídiche a prece dos mortos: o Kadish.

"O elemento em que habito está na fronteira de uma noite." (LÉVINAS, 2008, p. 135), pois se relaciona a um futuro, um devir. Um ainda não é. O ex-Häftling e ainda não homem Semprún frui o canto dos pássaros. Esse canto o lembra a vida, um ainda foi e, uma possibilidade 
de vir a ser. Uma lembrança de fronteira. Entre o ser e o devir, ele colocase uma impossível tarefa que é aprender a arte do esquecimento: "Só o esquecimento poderia me salvar." (SEMPRÚN, 1995, p. 160).

\section{Considerações finais}

O que está na fronteira de uma noite? Onde está, portanto, a ruptura entre fruição e representação? Lévinas aponta a questão: "Mas por que meio o mundo da fruição resiste a uma descrição que tenderia a apresentá-lo como correlativo da representação?" (ANO? p.122). Se fruição não é correlativo de representação, seria autônomo, independente. E, no entanto, repercussão e ressonância possuem ligação entre si. Qual seria o sentido de pensar essa discussão sobre fruição e representação, senão sentir a ultrapassagem da fronteira sob a forma escrita? Não sendo possível precisá-la, talvez o seja indicá-la.

A essa altura, uma questão se evidencia: Não se pode contar sobre algo que não se pode conceber, e não se pode discorrer sobre algo indizível. É de convir que a transliteração dessas memórias em linguagem já contém em si uma semente de uma possibilidade de compreensão. Isso fortalece a compreensão de que as imagens são o ponto essencial para leitura dos relatos da Shoah. Considerá-los relatos de indizíveis, inenarráveis, etc, só me parece uma tentativa de neutralizá-los, enquanto parte importante do humano - como reprimir a barbárie que não se deseja enxergar, mas que passa cotidianamente diante dos olhos.

Ao transliterar suas memórias, os sobreviventes deixam sementes de instantes, catalisadores de repercussões. Observe também que a discussão dos sobreviventes no caminhão, relatada por Semprún, era essa: se perguntavam como haveriam de contar, qual seria a melhor forma de dizer o que havia acontecido ali. Quando falo em transliteração, refiro-me à tentativa de colocar em uma língua, outra. É transformar significados formais, é 'dizer de outra forma, que não assim' ${ }^{11}$.

Compartilhar um sentido, para que ele deixe de ser apenas uma verdade individual, e possa fazer parte das verdades alheias. Só assim a experiência do Lager deixa-se de viver entre a realidade e o sonho. É desta forma que ela desanuvia-se e torna-se uma imagem que pode ser visualizada, e, transliterada. Ela é presentificada. Em Jorge

${ }^{11}$ Aqui, refiro-me mais uma vez ao poema de Celan. 
Semprún, ela é insuportável: "A felicidade da escrita, a essa altura eu já começava a saber, jamais apagava essa desgraça da memória. Muito pelo contrário: aguçava-a, escavava-a, reativava-a. Tornava-a insuportável." (SEMPRÚN, 1995, p. 160).

Diz Bachelard: "As ressonâncias dispersam-se nos diferentes planos da nossa vida no mundo; a repercussão convida-nos a um aprofundamento da nossa própria existência" (2008, p. 7). Inicialmente, esse par conceitual de Bachelard permeia toda a leitura feita. $O$ segundo capítulo enseja com mais profundidade essa tentativa: uma leitura. Uma proposta de resumo do que é dito nos relatos seria algo inviável, tendo em vista que eles são entendidos como instantes, ou, pontos resgatados de uma constelação. Não há resumo porque não há uma história linear.

Esses pontos são entendidos aqui como imagens. Imagens que questionam, interrogam. O leitor é interpelado pelas imagens nebulosas do Lager. Atingem "as profundezas antes de emocionar a superfície" (BACHELARD, 2008, p. 7). Que precisam encontrar um ponto em que seja reflexo na mente daquele que lê, e só então proporcionar um leque de possibilidades.

Em A intuição do instante (2010), Bachelard indica três passos para o rompimento com o tempo horizontal: "romper os contextos sociais da duração"; "romper os contextos fenomênicos da duração" e, finalmente, "romper os contextos vitais da duração" (p. 96). É preciso não atribuir-se tempo a si e aos outros, às coisas e ao tempo da vida: "Somente então se alcança a referência autossincrônica no centro de si mesmo, sem a vida periférica. De repente toda a horizontalidade plena se desfaz. O tempo já não corre. Ele jorra.” (2010, p. 96).

Ao final, a mão fria da morte, não é senão a garra fria da desrazão, barbárie de uma razão, que é fruto de uma modernidade nascida da opressão e exploração do homem pelo homem. Contra essa mão fria, há elementos no humano que lutam contra (WIESEL, 2006, p. 106).

Contra ela, também a voz do poeta se insurge: "Uma mão fria aperta-me a garganta e não me deixa respirar a vida" (PESSOA, 2006, p. 159). Debaixo de um frio intenso, as horas cinzentas desassossegam o tempo, que envolve o mais desperto dos corações em 'mãos gélidas' ${ }^{12}$, e transforma uma vida em 'uma noite mil vezes aferrolhada': "A última noite em Buna. Mais uma vez, a última noite. A última noite em casa, a

${ }^{12}$ PESSOA, 2006, p. 159. 
última noite no gueto, a última noite no vagão e, agora, a última noite em Buna. Por quanto tempo ainda nossa vida se arrastaria de uma "última noite" a outra?" (WIESEL, 2006, p. 89).

\section{Referências}

BACHELARD, Gaston. A intuição do instante. 2. ed. Tradução de Antonio de Padua Danesi. São Paulo: Verus, 2010.

BAUMAN, Zygmunt. Modernidade e Holocausto. Tradução de Marcus Penchel. Rio de Janeiro: Zahar, 1998.

BENJAMIN, Walter. O anjo da História. Organização e Tradução de João Barrento. Belo Horizonte: Autêntica, 2012 (Coleção Filô/Benjamin).

BUBER, Martin. O caminho do Homem segundo o pensamento Chassídico. Tradução de Claudia Abeling. São Paulo: É Realizações, 2011.

CLASTRES, Pierre. Arqueologia da Violência. 3. ed. Tradução de Paulo Neves. São Paulo: Cosac Naify, 2014.

GORODOVITS, David. Na espiral do tempo: uma viagem pelo calendário judaico. São Paulo: Sêfer, 2008.

HERSON, Bella. Almas Tatuadas. São Paulo: s/Ed, 2009.

JAFFE, Noemi. O que os cegos estão sonhando? O diário de Lili Jaffe (1944-1945). Texto final de Noemi Jaffe e Leda Cartum. São Paulo: Editora 34, 2012.

LEVI, Primo. Se isto é um homem. 8. ed. Tradução de Simonetta Cabrita Neto. Lisboa: Editorial Teorema, 2010.

LÉVINAS, Emmanuel. Novas interpretações talmúdicas. Tradução de Marcos de Castro. Rio de Janeiro: Civilização Brasileira, 2002.

LÉVINAS, Emmanuel. Totalidade e Infinito. 3. ed. Tradução de José Pinto Ribeiro. Lisboa: Edições 70, 2008.

LÉVINAS, Emmanuel. Humanismo do outro homem. 4. ed. Tradução Pergentino S. Pivatto et al. Petrópolis: Vozes, 2012.

LÖWY, Michael. Walter Benjamin: aviso de incêndio: Uma leitura das teses "Sobre o conceito de história". Tradução de Wanda Nogueira Caldeira Brant. São Paulo: Boitempo, 2005. 
OTTE, Georg; VOLPE, Míriam Lídia. Um olhar constelar sobre o pensamento de Walter Benjamin. Fragmentos, número 18, p.35-47, Florianópolis, jan-jun de 2000.

PESSOA, Fernando. O livro do desassossego. São Paulo: Companhia das Letras, 2006.

RAJCHMAN, Chil. Eu sou o último judeu: Treblinka (1942-1943). Tradução de André Telles. Rio de Janeiro: Zahar, 2010.

ROUDINESCO, Elisabeth. A parte obscura de nós mesmos: uma história dos perversos. Tradução de André Telles. Rio de Janeiro: Zahar, 2008.

SCHOPENHAUER, Arthur. A arte de escrever. Tradução de Pedro Süssekind. Porto Alegre: L\&PM, 2016. (Coleção L\&PM POCKET, v. 479).

SEMPRÚN, Jorge. A escrita ou a vida. Tradução de Rosa Freire D’Aguiar. São Paulo: Companhia das Letras, 1995.

SONTAG, Susan. Diante da dor dos outros. Tradução de Rubens Figueiredo. São Paulo: Companhia das Letras, 2003.

SPIEGELMAN, Art. Maus. Tradução de Antonio de Macedo Soares. São Paulo: Companhia das Letras, 2009.

SZPILMAN, Wladislaw. O pianista. 2. ed. Tradução de Tomasz Barcinski. Rio de Janeiro, Bestbolso, 2008.

WIESEL, Elie. A noite. 3. ed. Tradução de Irene Ernest Dias. Rio de Janeiro: Ediouro, 2006.

Recebido em: 11 de outubro de 2017. Aprovado em: 8 de dezembro de 2017. 